\begin{tabular}{|c|c|c|}
\hline Gazi & $\begin{array}{l}\text { GAZi iKTISAT VE ișLETME DERGISI } \\
\text { GAZi JOURNAL OF ECONOMICS \& BUSINESS }\end{array}$ & Giid \\
\hline $\begin{array}{l}\text { KADEMIK } \\
\text { YINILIK }\end{array}$ & & \\
\hline
\end{tabular}

\title{
Transfer Pricing and Customs Valuation Overlap: Is It Possible to Bridge Two Worlds?*
}

\author{
Muhsin Atci ${ }^{* *}$ \\ ** Tax Inspector, Vergi Denetim Kurulu, Ankara Büyük Ölçekli Mükellefler Grup Bşk. Adakale Sokak No:20 Ankara, \\ TURKEY. muhsinatci@gmail.com ORCID ID: https://orcid.org/0000-0003-3225-1421
}

\begin{abstract}
ARTICLE INFO
Received: 30.09 .2019

Accepted: 15.01.2020

Available online: 12.02 .2020

Article Type: Research

article

Keywords:

Transfer Pricing,

Custom Valuation,

Price Adjustment,

WCO, OECD

ABSTRACT

Importation of a good from a distinct and legally separate entity of the same group company is regarded as related party transaction. Such a case is treated as a risky transaction by both for customs and revenue administrations because of possibility of influenced price declared by the company. For a long while WCO and OECD, as supra national bodies, have strived to find a deal between these two separate worlds but, unfortunately, a definitive approach could not be developed yet. The existence of two sets of rules and two different administrative bodies dealing with income taxes and customs duties, make crossborder trade overly complicated and costly. In this paper, after evaluating significance of the problem a response is intended to discuss for the question of "how could customs valuation and transfer pricing overlap be reconciled by considering favor of the whole stakeholders?"
\end{abstract}

Transfer Fiyatlandırması ve Gümrük Kıymeti Çakışması: İ́ki Ayrı Dünyayı Uzlaştırmak Mümkün mü?

\begin{tabular}{|c|c|}
\hline MAKALE BİLGİSİ & ÖZ \\
\hline $\begin{array}{l}\text { Anahtar Kelimeler: } \\
\text { Transfer } \\
\text { Fiyatlandırması, } \\
\text { Gümrük Kıymeti, } \\
\text { Fiyat Düzeltmesi, } \\
\text { WCO, OECD }\end{array}$ & $\begin{array}{l}\text { Bir malın aynı gruba ait farklı ve yasal olarak ayrı bir şirketinden } \\
\text { ithalatı bir ilişkili taraf işlemi olarak kabul edilir. Böyle bir işlem beyan } \\
\text { edilen satış bedelinin aradaki ilişkiden etkilenmiş olma ihtimali } \\
\text { nedeniyle hem gümrük hem de gelir idareleri tarafindan riskli işlem } \\
\text { olarak değerlendirilir. Uzunca bir süredir WCO ve OECD, ulusüstü } \\
\text { kurumlar olarak, bu iki dünya arasında bir çözüm bulabilmek için çaba } \\
\text { sarfetmektedirler, fakat maalesef henüz belirli bir yaklaşım } \\
\text { geliştirilememiştir. Gelir üzerinden alınan vergiler ve gümrük vergisi } \\
\text { ile ilgili iki kural setinin ve iki farklı idari birimin varlığı sınır ötesi } \\
\text { ticareti oldukça karmaşık ve maliyetli hale getirmektedir. Bu } \\
\text { çalışmada sorunun önemi vurgulandıktan sonra "Transfer } \\
\text { fiyatlandırması ve gümrük kıymeti çakışması bütün tarafları ikna } \\
\text { edecek şekilde nasıl uyumlaştırılabilir?" sorusuna bir cevap verilmeye } \\
\text { çalışılmıştır. }\end{array}$ \\
\hline
\end{tabular}

* Doi: https://doi.org/10.30855/gjeb.2020.6.1.005 


\section{Introduction and background}

Determining the value of goods subjected to importations between associated companies is substantially significant for taxpayers, in particular multinational corporations since "the customs value of imported goods is primarily used as the basis for determining customs duty liability for imported goods where ad valorem duty applies"(WCO, 2018) and tax administrations figure taxable profit through value of the goods. At the first glance, the price of imported goods is presumed to be determined by taxpayers. Partially that is correct, yet, in fact, both administrations have their own valuation methodologies leading taxpayer to assure the price appearing in the transaction between associated companies whether it reflects the value that if this transaction takes place between unrelated companies. However, involvement of those two sets of rules and two unrelated administrations in the same transaction complicates the situation not only for the taxpayers, but also for the administrations. Nevertheless eventual loser would be the taxpayer because of the possibility of being subjected to unfair taxation. On a given import of a good, for instance, customs intend to get the benefit of high valuation of the import for collecting more duty (Kitaura \& Cremer, 2009, p. 73). Tax administrations, on the other hand, would strive to decrease the import value in order to keep deductible cost low from domestic price. Even within a multinational enterprise, at one side to avoid high custom duty, importation value of a good could be wanted to keep as low as possible, while not to pay high amount of income tax, higher transfer prices might be interested in to take advantage of greater deductions.

Conflict between transfer pricing and custom valuation appears typically in the intra group transactions. Economic relationship between affiliated enterprises cannot not be regarded as same as transactions between unrelated companies. Apparently, there is a potential risk that custom duties and income taxes would be manipulated through under or over pricing because a multinational enterprise $(\mathrm{MNE})^{1}$ intends to maximize its consolidated profit. From that aspect, the taxpayers, particularly multinational enterprises, consider valuation of goods as one of the tools that arrange their profitability through the tax burden in regard with custom duty and income tax. Significance of transfer pricing and custom valuation is ever-increasing since multinational enterprises possess more shares in the volume of world trade with the effect of globalization. For instance, approximately one third of global trade is took place between affiliated companies (WHO, 2013).

Typically, within the body of a government, custom administrations and tax offices are predominantly organized separately as two different organizations either under the ministry of finance or under separate ministries as in the case of Turkey. These two fields also link with separate supranational organizations. The World Trade Organization (WTO) introduced Custom Valuation Agreement for customs in 1994 and vast majority of the countries are signatories to it and as a binding consequences of the agreement, the countries customs rules are designed in accordance with the agreement. As for transfer pricing, the Transfer Pricing Guidelines for Multinational Enterprises and Tax Administrations issued by Organization of Economic Cooperation and Development (OECD) in 1996 is one of the international guide for not only OECD member countries also for the non-member countries. Basically, these two frameworks are intended to achieve arm's length value of the goods in related party transactions. In effect, the only possible way to determine whether the relationship has influenced the price in any given controlled transaction is to compare such transaction with similar uncontrolled transactions (Jovanovich, 2017, p. 140). However those two sets of rules can have differing methods or yield different valuation results.

As mentioned before, even though these two systems are not designated in same fashion, purpose of them are the same; to ensure the value of goods reflecting the arm's length price. In this sense, the arm's length standard normally requires reference to comparable transactions and relevant comparable data (Gustafson, 2006). Arm's length price is a benchmark that indicates artificial transfer price that deteriorates influence of objective market forces. Profit realized by an enterprise from controlled

\footnotetext{
1 In OECD Guidelines Multinational Enterprises are described as follow, "these usually comprise companies or other entities established in more than one country and so linked that they may co-ordinate their operations in various ways. While one or more of these entities may be able to exercise a significant influence over the activities of others, their degree of autonomy within the enterprise may vary widely from one multinational enterprise to another. Ownership may be private, state or mixed".
} 
transactions should not be distorted by the relationship that exists between the parties, in other words, arm's length price is to ensure that the taxable profits reported by the members of an MNE in the countries where it operates reflect the economic activity of the MNE in each of these countries (Silberzten, 2009, p. 38). Regarding the valuation of imported goods, customs consider the value of the goods based on the time of the transactions that is the price actually paid or payable for the good when sold for export to the country of importation, with certain adjustments. From the taxpayers' point of view, transaction value is, also, most preferable method because taxpayers could readily provide required paper works in proof. In WCO's view "the Agreement is intended to provide a single system that is fair, uniform and neutral for the valuation of imported goods for Customs purposes, conforming to commercial realities and outlawing the use of arbitrary or fictitious Customs values". However, it is perceived that vague regulations of customs does not provide a useful direction to the taxpayers (Methenitis \& King, 2010). Those customs treatment regulations apply, in particular, to intra group transaction.

For the purpose of seeking harmonization of customs valuation and transfer pricing two joint conferences were held by OECD and WCO in 2006 and 2007. Afterward, WCO and OECD held joint workshop in September 2013 in Pretoria. These meetings have included whole stakeholders such as the WCO, OECD, WTO, customs administrations, tax administrations, and the private sector. Although they have reached agreement on the areas of concern and common problems, no concrete "solutions" have been developed to date (PWC, 2013). The conflict of these two sets of rules is a priority issue for Customs administrations and the business sector, in particular. Thus, the workshops mainly examined to what extent information contained in a transfer pricing study may be useful to Customs when verifying the Customs value of multi-national enterprise transactions (WCO, 2013).

\section{Significance of the problem}

The valuation overlap could occur in different circumstances and prominence. Development level of the countries as well as being importer or exporter of capital, have influences in the context of consequences of the conflict. As a result of dependency of the capital importing countries on foreign direct investment, as seen in all developing countries, the portion of customs tax among total tax revenues is crucial. In parallel, dominance of the direct taxes on tax revenues of developed countries is relatively insignificant in terms of addressing and reducing the valuation overlap.

Besides government interests, consequences of the overlap for each stakeholders appear in various forms. In this study main stakeholders, tax administration and customs authority are discussed under the government interest and, taxpayers, in particular MNEs are analyzed with respect to their interest and altered economic patterns. Additionally a midway solution which satisfies stakeholders is evaluated.

\subsection{Government in conflict}

\subsubsection{Revenue}

In an import dealing between associated parties, customs valuation and transfer pricing rules primarily targets to serve governments by assessing and collecting taxes levied on the taxpayers. Customs duty and income tax (Corporation Tax), as indirect and direct taxes, have separate functions and influences in the economy when they are imposed (Duerto, 2012, p. 16). Their roles within the government revenue could be seen through a comparative evaluation from the historical background to date.

Customs duty have had particular importance in the government revenue in the past, but today it is losing ground gradually with the changing policies to liberalize international trade by lifting barriers involving customs duty and tariffs, but still has a vital role in the developing countries (Ibid, 2012, p. 18). From the administrative point of view besides customs duty, customs administration collects VAT and private consumption tax from the goods that subject to importation in front. Particularly, in developing countries those two consumption taxes in question are the main source of the government revenue. In contrast, corporation tax is gaining ground in parallel with the jumping share of MNEs in the international trade both developed countries and developing countries attracting foreign direct 
investment. When the MNEs' intense dealings with their affiliated parties are taken into consideration, obviously transfer pricing system can influence immense amount of revenue sources ( Ritchie et al., 2013, p. 16).

An exemplifying case would clearly display the adverse consequences of the conflict. Assuming that a kitchen appliance distributor is having examined by a tax inspector with regard to transfer pricing compliance in the transactions with an affiliated manufacturer. In the findings of examination, the price determined in the controlled transaction is not accepted at arm's length and is needed to adjust to profit margin upwards. In other words, price of goods imported from related entrepreneur is overvalued, thus, customs duty paid was overstated. Also, operational profit of the company does not at arm's length range which needs to be adjusted. Corporation tax would be increased and, as a result of the adjustment custom duty would be decreased. In this case, overall change in the government revenue depends on the amount of decrease of customs duty and increase of the income tax. The lower the customs duty rate, the greater the net revenue gain from transfer pricing adjustment (and also the greater the incentive of the importing company to over price the import.)

\subsubsection{Consistency and reliability of the government}

Enhancing prosperity of a country by satisfying conditions of good governance, as expressed through factors like reliability, predictability and accountability, is seen one of the necessary arguments in the most recent trends on government. Solidarity and unity of the government are ever since one of the hot topics of discussions on good governance. (Louis and Zinkin, 2019, p. 64) Outcomes of those discussions suggest that government should apply rules equally and implementations applied by a unit should be binding for the other government units.

Particularly, certainty of taxes, one of the principles of taxation proposed by Adam Smith, has essential role in order to provide trustable environment for the entrepreneurs and to attract foreign direct investment to the country ( Loknathan, 2018, p. 41). Different applications of the different governmental units undermine consistency and confidence in the government. From the taxpayers point of view conflicting rules of the government could be counted one of the stressing issue which distorts market conditions and taxpayers targets. In particular foreign entrepreneurs prefer to invest into a safe environment in which return of the money is determinate and not subject to unexpected enforcement (Ainsworth, 2007, p. 61).

Conflicts between customs valuation and transfer price take place in pre and post import conditions. First, after assessment of the imported goods in accord to transaction value by customs, tax administration could find value of imported good overstated and contrary to the transfer pricing methods, probably be ended up more tax payment than expected, and if the taxpayers are reassessed after an audit, the taxpayer will a pay fine in addition (Ping and Silberztein, 2007, p. 36).

Second, the price determined in lieu of APA could be refused by the customs administration at the time of importation which would lead taxpayers simply into an unresolvable conflict because there is no halfway solution to satisfy both sides in this case.

\subsubsection{Administrative cost}

Obviously, the dual structure in customs and transfer pricing valuations complicates procedures, increases administration costs and wastes time as well. That type of structure is far from effective and efficient governing principles.

Customs duty and transfer pricing are grouped on the revenue side of the budget which are respectively examples of direct and indirect taxation. One government unit administers the whole direct and indirect taxes except customs duty. As such, the conflict attributed to the appraisal of the imported goods are administrated by two parallel organizations and separate administrative models. In this sense two government units have separate buildings, tools, officers, two separate administrative regulations, two different audit policy, etc. To some extent separate organizations could be acceptable depending on additional irrelevant tasks on the units but beyond those, lack of coordination between relevant administrations duplicates procedures in several implementations such as assessment of the 
same transaction, auditing same taxpayer for the same transaction or separate documentation requirements.

\subsection{Taxpayers dilemma}

\subsubsection{Double taxation}

If customs department and tax administration apply their rules without coordination, the result for the taxpayer will be over payment. That situations can arise in post import situation when retrospective downward adjustment is applied to ensure arm's length price the new price is not considered by customs administration and the taxpayer also incurs additional customs duties on the same set of import transactions. This form of "double taxation" can be especially frustrating for taxpayers because it arises from seemingly contradictory positions taken by the tax and customs authorities (PWC, 2013). Transfer pricing compliance enforced by tax administration does not provide for customs compliance simultaneously. In a typical example, customs authorities do not accept prices set by transfer pricing methods and do not apply retrospective adjustments.

\subsubsection{Impacts on taxpayer's compliance}

Existence of the dual structure brings several identical regulations along. Those are that methods that are used to determine import value, somewhat elaborate documentation requirements and audit systems. As the consequences of dual structure taxpayers are exposed to risk of multiple audits and possible adjustments. Two sets of rules applied to the same transaction without any coordination drives taxpayers to choose the way which reduces the tax liability more. To avoid lose-lose situations, companies may evaluate whether, based on domestic legislation, specific programs are available to integrate their commercial and invoicing practices (including price adjustments) within their procedures for determining and declaring the customs value of goods imported (TPA Global, 2011). Being subjected to tax audit by either customs or tax administrations are unpleasant for it is enormously costly and discrediting. To avoid such a confrontation high degree of compliance to the rulings are sensible. However, in the conflicting situation, when the taxpayers seek relief alternatives options out of legal border could be preferred in practice.

\subsubsection{Is it necessary to reconcile these two systems?}

Major stakeholders that involve the transfer pricing custom valuation overlap are multinational companies and two government organizations. Each stakeholders, as a matter of fact, is influenced the activity of the other parties. As such, taxpayers must comply with both guidelines otherwise they may find themselves subject to incremental taxes, duties and penalties as well as subject to the burden of complying with potential onerous customs valuation methodologies. Thus, to reconcile those two systems is essential to prevent market distortion, inconsistency of the governmental rules, unfair treatment against taxpayers and waste of money and energy.

Basically, the problem being discussed in this paper appears in a particular situation; that is transaction of importation of goods between associated parties which are located in different jurisdictions. Portion of such transaction among the world trade, which is believed enormously expanded, puts this discussion crucial position in terms of efficiency, effectiveness, market distortion since in every transaction prices are needed to be determined two times by the same government.

Taxpayers are exposed to risks of potential examination which could be conducted by two government units. Uncertainty resulted dual structure, reduces consistency and reliability of the government and undermines the investible country argument.

Customs administration involves the transaction at the time of importation but from the aspect of direct tax purposes tax administration interests in the transaction after importation took place through retroactive adjustments in which price applied in the custom entry would be changed which also causes double taxation because of rejection of the new price by customs. Unfortunately, no refund mechanism exists to provide relief for the burden resulting from increased custom duties paid due to a price alignment. 


\section{Problem statement}

\subsection{The root causes of conflict between customs and transfer pricing}

\subsubsection{International commitment or legislation versus guideline}

Standards of customs valuation and transfer pricing are set by supra-national bodies. The calculation of the value for customs duty is prescribed by the WCO Custom Valuation Agreement that signatory countries have liability to comply with it, whereas the transfer price is determined based on advisory guidelines which do not burden any commitment to the countries. But uniqueness of the guidelines made it broadly popular. As the WTO Valuation Agreement engages in international rules of trade, the OECD sets out international taxation principles, the objectives of the standards of each in detail are different, but they both dedicate to promote liberal economic policies and free movement of capital.

\subsubsection{Organizational disconnection}

In parallel with the international system, a separate structure is usual in national level, as well. Broadly speaking, customs and tax administrations are organized under the different units but mostly in the same ministry. Also, it is possible to confront that these two administrations could be placed under the different ministries in which hardly do communicate two administrations each other. Especially in Europe, the fact that transfer pricing and customs valuation are governed by two different government entities. In the EU, the tax treatment of transfer prices is based on EC Directives and member states' national legislation; these measures, in turn, are based on guidelines produced by the OECD. The value of imported goods for customs duty purposes, however, is determined in accordance with EC Regulations which incorporate the provisions of Article VII of the GATT and the WTO Agreement on the interpretation of that Article (Renaud, 2010, p. 3).

Except very few unified administrations, the typical practice is customs and transfer pricing are governed through different governmental entities. Certainly, close administrative structure, at least, provides the advantage of close communication possibility. In other words, separation brings communicational disconnection and indifferences between two entities which worsen inherited conflict.

\subsubsection{Two different objectives}

Despite serving same government, revenue and customs administrations focus goals which oppositely different from one another in the determination of value of imported goods. In the importing country, tax authorities strive to increase taxable income by reducing import price, whereas customs authorities aim to increase customs value.

Tax administration focuses on direct taxes and through the transfer pricing principles and objectives intends to prevent erosion of the direct tax base. In other words, it intends to prevent overpricing of importation of the international tradable goods.

On the other hand the customs authorities aims indirect taxes. Therefore, it focuses on the most important element of the tax base in imports which is customs value of imported goods and to prevent not to be declared under its value. Thus, the customs authorities are sensitive about lower price declaration of imports goods, but high price declaration is not questioned but out of a very exceptional circumstances.

Here, position of the taxpayers should be underlined. Naturally, the taxpayer or importer usually wants to pay the lowest possible tax. Despite this natural inclination, there is a conflict of interests from the taxpayer point of view regarding the value of the transaction. To be able to reduce the payment of customs duty, the customs value should also be low. However, in order to pay a low amount of income tax, the value for transfer pricing purposes should be high (Malm, 2009, p. 37). 


\subsubsection{Declination of agreement}

This situation mostly related with customs administration policy. It is frequently confronted in international practice that customs administrations examine the prices even determined in compliance with Advance Price Agreement between a taxpayer and the revenue administration. In other words, since the customs is not part of it, such an agreement signed between a taxpayer and the tax administration has not binding power on the custom administrations.

\subsubsection{Additions and deductions in the computation of tax base}

WTO agreement prescribes transaction value as customs duty base whereas among the other methods the CUP method is considered that it provides the most direct and reliable means of establishing an arm's length price. Theoretically, two disciplines intend to provide market price in the determination of tax bases by referring transaction value and arm's length price, technically legislative deductions and additions embodied in customs rules hinder to obtain identical values. On the other hand, to provide a meaningful result in the application of the CUP method, the factors that influence objective comparability are needed to be taken into account. Those are, as counted in the Guideline and exemplified in Transfer Price Customs Valuation Memorandum; characteristics of the property (i.e. physical features of the good, its quality and reliability and the availability and volume of supply), functional analysis (i.e. comparison of the functions taken on by each party taking into account assets used and risks assumed), contractual terms (i.e. how the responsibilities, risks and benefits are divided among the parties), economic circumstances (i.e. the markets that each party operates in), and business strategies (i.e. innovation and new product development, and degree of diversification).

Principally those two disciplines aim to rely on the market price to calculate tax bases in the transactions. However, transfer pricing methodology reaches arm's length range in the course of general accounting standards whereas customs reaches transaction value by applying deductions and additions determined in the customs law, which are fixed. For example, a royalty or commission is determined as to be included in the price paid or payable in the customs duty purposes but application of transfer pricing intangible goods are treated separately from the tangible goods subjected to importation. Those type of material differences can result in different import values in the application of customs and income tax system.

\subsubsection{Application of different methodologies}

As mentioned earlier customs and transfer pricing systems follow different methodologies. Although those methods are named differently same underlying principles could be encountered. As those methods are shaped by objectives of either systems, different values are computed once even same method is applied on the same transaction.

\subsubsection{One result versus a range of results}

The methodologies used for customs purposes produce a certain value which represents the customs base, however the transfer pricing methodologies may produce a range of figures that are acceptable for establishing whether the conditions of a controlled transaction are arm's length. The tax rules provide for a range of acceptable values, rather than trying to specify a definitive price based on a rigid formula. This flexibility, while needed because transfer pricing is not an exact science, creates uncertainties for both taxpayers and revenue authorities (Renaud, 2010, p. 3).

\subsubsection{Aggregated transactions}

For income tax purposes, it is preferred that taxpayers set prices separately for each transaction between related parties, however in some specific situations, transactions are so closely linked or continuous that they cannot be evaluated adequately on a separate basis and the transactions are priced on an aggregate (or bundled) basis in which profit base methods might be more useful. The issue is whether one can determine the correct transfer price when prices have been either bundled or unbundled. 
For customs purposes, each transaction is appraised separately except price formulae or price review clause applications. An unbundled price may not include costs for items such as royalties, assists, commissions, research and development, etc. These costs may be required by legislation to be added to the price paid or payable to arrive at the transaction value for customs.

Practical difficulties in applying strict transactional approaches have resulted in transfer pricing practices which often aggregated related party transactions to test the arm's length nature of the profit outcomes rather than prices (Ritchie, 2009, p. 251).

\subsubsection{Timing of valuation}

One of the fundamental discrimination between customs and transfer pricing disciplines have arisen in the application time. For customs purposes, naturally, goods are valued at the time of importation; for income tax purposes, goods are generally valued in the one year period after importation which means that it is likely that the goods will be valued at different times. That difference is attributable to the characteristic of direct and indirect taxation. Indirect taxes tend to be more mechanical and strict than direct taxes. Transfer pricing and its effect on income tax usually takes place after some time which is changeable by the country practices, for instance in the case of installment taxation transfer pricing begins to consider on income tax purpose no earlier than three months because of fiscal year that income tax return is mostly given in the third to fourth month of following year. With respect to time of tax returns, also, time of audit takes place in different times.

\subsubsection{Time of exchange rates}

For customs purposes, the rate of exchange to be used for assessment of the import duty is the rate current on the date of direct shipment to the importing country of the goods whose value is to be determined in local currency. For income tax purposes, an exchange rate is determined in accordance with generally accepted accounting principles. Normally, it is the rate of exchange prevailing at the time of the transaction. This can result in the use of different exchange rates, and therefore result in different values.

\subsubsection{Retroactive price adjustments}

Post importation adjustment, in fact, is one of the problematic issue that causes costly results for the taxpayers. This contentious issue gridlocks the nexus between customs authority and tax administration. Any downward adjustments in the transfer price charged to taxpayers resulting from competent authority, audit, appeal or other taxpayer request settlements would not be reflected in the value for duty declared afterward because of legal prohibition which could be seen in many of the countries customs act. This is a common discrepancy between the income tax transfer price and the value for duty of imported goods.

\subsection{Characteristics of the overlap in Turkey}

Customs valuation methodology is consistent with the indirect taxes which are computed on the transaction value. In addition, customs duty used to be the main source of revenue to the government in the early 1900's but from the mid 1900's on preventive and protective functions of the customs came into prominence rather than the revenue collection purpose as a result of liberation policies in international trade. Governments refer custom taxes to protect the domestic producers through controlling the price of the certain goods which means to suspend liberal market balance. On the other hand transfer pricing principles are, merely, applied to ensure the price appears in liberal market conditions. Thus, various objectives of the administrations obstructs to organize them under one roof.

In emerging economies TP regulations can sometimes be seen as a deterrent to FDI. It is often practiced that strict regulations on TP front could drive FDI to other economies resulting in prisoner dilemma for the tax authorities. However by the turn of the millennium with Turkey having emerged as part of the league of big economies that could not be ignored anymore and the country introduced TP regulations more or less on the lines of the developed economies without the fear of its impact on FDI flows in a radical manner. 
In accordance with customs law, the payments that unnecessarily paid as customs duty to the government, could be refunded upon the application of the taxpayers within three years. However, in the application of the statute, tax refund is carried out where the tax return is canceled, or taxpayers reject the tax return for material mistakes or contrary to the agreements or in the cases that conditions determined by Council of Ministers by virtue of the international agreement that Turkey is the signatory county. These conditions are limited and not cover transfer pricing adjustments. In other words, there is no mechanism in the CL to correct the tax return or refund the excessive payment that in the case the importer erroneously declare a higher value.

Taxpayer has to give an additional declaration if he realizes that the import value of the good was erroneously stated lower than the market value. In this case the taxpayer pays additional tax with $\$ 100$ fee for per additional declaration. Obviously, companies that price in accordance with transfer pricing principles would be in difficult situation in both cases. For instance, assumed that a company determines its price with regard to transfer pricing principles and uses it along the year in countless import transactions with an associated company. The company could not claim refund of overpayments, if the company notice that the transfer price was mistakenly over valued, on the other hand the customs authority claims surplus taxes with $\$ 100$ fine for per declaration if the transfer price was determined at a lower price.

In Turkey case, different from the majority of the countries, separation of the administrations are certain; customs are administrated by the Ministry of Customs and Trade and transfer pricing issue is engaged by the Ministry of Finance. These two ministries have the identical degree of importance and power, but eventually they have not enforcement power on one another. As mentioned in the OECD guideline "Countries that have a separate administration may wish to consider modifying the exchange of information rules so that the information can flow more readily between the different administrations" ( OECD TP Guideline 1.79).

Turkey's membership to the Customs Union significantly influences the discussions on transfer pricing and customs valuation conflict. It is about the volume of foreign trade with European Union. As seen in the table II, EU countries are the major supplier of the Turkish import volume and successive country is Russia. First of all, import with EU countries are not subject to customs duty as a result of the principle of the free movement of goods. Therefore, the conflict between customs valuation and transfer pricing conflict is not a matter in the import with EU countries. Those transactions are only be considered by transfer pricing principles. Additionally, second country that Turkey import most is Russia. This is because Russia is the biggest supplier of the Turkey's energy needs in terms of natural gas and petrol which are not subject to conflict between transfer pricing and customs valuation overlap, as well.

\subsection{Is the reconciliation feasible?}

In fact, these two systems are not opposite sharply in any case. There are some attributes that could facilitate reconciliation. First of all, to be serving to the same government fundamentally shape the values of the administrations. In this sense, a higher authority could intervene the conflict by taking initiative and lead the units to realize the overall benefit of the government. But from the technical point of view these two systems converge in the definition of the value.

It should be noted that both the guidelines set by the OECD and WTO abide by the arm's length principle, and both aim at determining 'fair' price for transactions that take place between related parties (Jovanovich, 2017, p. 96). Basically the two sets of rules are established to ensure application of fair market value to the transactions, thus, systems seek market value by applying different methods. Even though, controversially, both discipline could reach out dissimilar consequences that are in accordance with the purpose of the systems, in the application of arm's length principle to the same case.

Arm's length price is a term which originally belongs to transfer pricing field. A clear definition of it could be found in the OECD Guidelines glossary as below, "The international standard that OECD member countries have agreed should be used for determining transfer prices for tax purposes. It is set forth in Article 9 of the OECD Model Tax Convention as follows: where "conditions are made 
or imposed between the two enterprises in their commercial or financial relations which differ from those which would be made between independent enterprises, then any profits which would, but for those conditions, have accrued to one of the enterprises, but, by reason of those conditions, have not so accrued, may be included in the profits of that enterprise and taxed accordingly". In regular condition price in the uncontrolled transaction constitutes itself in accordance with the market condition. However, the connection between related parties distort ordinary market condition and which ultimately results biased prices. Hence, the methods recognized by transfer pricing regulations are applied to ensure to form of arm's length prices in the controlled transactions.

An identical approach is confronted in the custom regulations. Price come up in the controlled transactions are controlled with "transaction value" in the Valuation Agreement. Article 1 of the Valuation Agreement says that "The customs value of imported goods shall be the transaction value, that is the price actually paid or payable for the goods when sold for export to the country of importation..." and price in the transactions between related parties is determined in the Article 1.2 that "... In such case, the circumstances surrounding the sale shall be examined and the transaction value shall be accepted provided that the relationship did not influence the price..."

Even though, the term "Arm's length Price" is not mentioned in the Valuation Agreement, by referring "transaction value" same consequence with the Guide is aimed. Eventually, both disciplines aim to provide a price that is not influenced by the relationship between the parties.

Disparities between two systems theoretically set ground for conflict, however, conventional attitudes would be a base to reach reconciliation and ease the tension between two ways of valuation. Two disciplines understanding of the valuation of related party transactions in a parallel manner with identical principles but using dissimilar wording and language.

\section{Policy Options}

\subsection{Seeking policy alternatives}

The joint OECD and WCO workshops were the most serious attempt in which source of conflicts and possible remedies were discussed in the environment with relevant stakeholders involvement (Ping and Silberztein, 2007, p. 36). The first issue discussed was the usefulness of contemporaneous transfer pricing documentation for customs purposes. An MNEs TP documents could be useful for the customs authority since it often provides extensive information about the company's transfer pricing compliance requirements and could serve as dual purpose, especially if this documentation addresses the company's customs valuation requirements. The second issue was the development of a joint advance price agreement. This possible development was seen, at the conference, as promising, despite limited and contrasting experiences countries had so far. The use of a ruling involving both the revenue and customs authorities opens up the prospects for an effective, coordinated dispute prevention mechanism. The third issue discussed at the conference was the possible development of joint customs and transfer pricing audits. The objectives are that it would reduce the time and effort spent in audits by the taxpayer and the authorities, and to arrive to the extent possible at a common determination of the valuation of related party transactions that would be acceptable for both customs and tax authorities (Malm, 2009, p. 26).

It is obvious that the conflict on valuation would come up after importation so that the best strategy is considering and acting before the problem arises (Marsilla, 2008). Definitely, an importer is interested in having compatible values for both customs duties and income tax purposes, to do so the importer should pursue the way not to avoid the transaction value method. As such, in some cases through price review clauses or price formulae the importer should disclose a provisional price to the customs authority at the time of importation in order to review the final determination of the customs value. Thanks to that, the importer avoids losing repayments of duty in the case of an overvaluation and cannot be charged with potential penalties for undervaluation.

Besides price review clause, a joint advance price agreement has a function to prevent post importation conflicts. The customs authority should, if possible, be invited when an APA is discussed. 
An adequate APA is the best method available for the importer to avoid conflicting valuations (Ibid, 411).

It is important to manage and understand the differences created by the conflicts in order to effectively manage reconciliation. As the tension between customs valuation and transfer pricing is a globally considered concern, ideas on reconciliation possibilities have been expressed in various platforms. However, it should be noted that probable alternatives are needed to be divided as supranational and domestic base. As the client of this paper is determined as Turkish Prime Ministry, domestic remedies are evaluated. In addition, root causes underlying the conflict are analyzed to seek possible alternative combination.

\subsubsection{Time gap and conflicting objectives}

Differences on objectives and timing of implementation between two disciplines preclude any convergence attempt. Because, these disparities arise from inherent reasons. Indirect taxes are imposed at the time of transaction, in this case taxable event of customs duty is realized at the time of clearance when the imported goods are entered to the customs. ${ }^{2}$ When the taxable event is occurred customs duty is computed and incurred. On the other hand, taxable consequences of transfer pricing could be seen after the end of fiscal year. As considered the circumstances, it would be utopian to assume that tax authorities could shorten their time gap on the initiation of taxpayers and that transfer pricing analysis would start being held at each transaction (Duerto. 2012, p. 30). On the other side, it is difficult for customs to conceive customs valuation by not having a transaction based focus and not acting at the time of the import.

Likewise, different objectives of the customs and tax administrations are attributed to the inherited difference between computation of indirect and direct taxes. As a superficial remedy, price review clause mechanism mitigates the time and objective conflict to some extent by delaying determination of final value which would provide to adjust initial value declared at time of entry.

\subsubsection{Supra-national sources, administrative indifferences and two sets of rules}

OECD Guidelines is the mere source dealing with transfer pricing issues which are followed by many countries while establishing national tax laws on transfer pricing. As of customs valuation principles the WTO valuation agreement is a binding regulation which is required to be adopted by signatory countries. From this aspect, the major cause of the conflict could be attributed to the supra national separation. As a result of international separation, customs and tax administration is organized separately in the internal base. Even so, some countries attempt to unify customs and tax administrations which provides some advantages at the bottom line, but two sets of rules necessarily requires separate consideration. The administrative integration could be seen one of the solutions, however, both tax and customs administrations have their relevant and unique areas of expertise and the conflict surrounding related party transactions is only one of the issues those two administrations engage. Therefore, partial integration of the administrations could facilitate data sharing, audit planning and more coordination to mitigate the tension between two systems.

\subsubsection{Additions and deductions}

In computation of the tax bases specific additions and deductions are needed to be considered due to either statutory requirement or economic conditions. In terms of custom duty application, transaction value ${ }^{3}$ is accepted as custom value. According to statute, transaction value consists of price paid or payable plus statutory adjustments prescribed article 8 . The price paid or payable does not include certain specific costs which are needed to be added to it in determining the value for duty. Those are commissions and brokerage, packing, assists, royalties and license fees, post-importation payments or fees (subsequent proceeds), certain transportation and associated costs. ${ }^{4}$ Some of the costs, which could be included in the price paid or payable, are needed to be deducted which are

\footnotetext{
24458 no. Turkish Customs Act sec. 181.

${ }^{3}$ WCO Valuation Agreement Art. 1.

${ }^{4}$ WCO Valuation Agreement Art. 8.
} 
certain transportation and associated costs, costs arising after the goods have been imported, and import duties and taxes. Those deductions and additions are not necessarily taken into account in the income tax purposes. But in essence the price paid or payable, which is basis of customs value, and arm's length price are meant to refer to fair market value. Therefore, additions and deductions should not be seen as actual discrepancy between customs valuation and transfer pricing.

\subsection{Full integration}

When the reasons behind the conflict are realized, to seek a panacea for customs valuation and transfer pricing conflict is not a rational approach. Additionally, in my assumption, full integration of the customs and tax administration should be considered in a joint application of one set of rule instead of two. However, to avoid double taxation (or double non-taxation) the internal rules also are needed to be harmonized internationally (among jurisdictions) which is a supranational level discussion (Richard, 2007). Another issue is whether convergence is possible but what extent. The case for convergence does not necessarily mean that actual and full convergence is the only way to achieve cost savings simplifications and mutual benefits.

Departure point to integration of rules is emphasis of market value in the related party transactions both by customs system through referring uninfluenced transaction value and transfer pricing through arm's length price. As such, in essence both system target to achieve same non-influenced market price. As mentioned earlier, there are mandatory components of costs to add and deduct from the value for both customs and transfer pricing purposes. Even so, if the components can be identified and separated from the price, the core value should be an arm's length price and identical for both customs and transfer pricing (Malm, 2009).

Furthermore, the scope of customs valuation encompasses transactions with non-associated enterprises, which are out of the scope of transfer pricing, while the scope of transfer pricing encompasses export as well as import transactions and transactions consisting in the provision of services or transfer of intangible property, which may not be of great interest to customs authorities. In this case, a full integration of the authorities would bring up any other problems and complications in terms of conducting other functions of customs and transfer pricing.

\subsection{Second best option}

In domestic base, full integration is not viable due to the overwhelming influence of two supranational bodies, in particular legally binding WTO agreement. A possible way to solve or at least ease the tension, would be a policy mix that enhances harmonization of the two sets of rules. This policy mix should target pre import situation and post import situation by maximizing coordination and awareness both in administrations and taxpayers. To do so joint APA, application of retroactive transfer pricing adjustment and establishment of a review committee should be applied together.

\subsubsection{Joint advance price agreement}

As mentioned in the Guideline, an APA program can assist taxpayers by eliminating uncertainty through enhancing the predictability of tax treatment in international transactions and providing the taxpayers certainty in the tax treatment of the transfer pricing issues covered by the APA for a prescribed period. As such, thanks to a joint APA scheme, a taxpayer could proactively seek advance approval of the price in terms of customs and transfer pricing and could avoid possible post import adjustments. In fact, Marsilla argues that if a tax authority accepts a price as an arm's length price, this should be evidence enough for the transaction value to be sufficient (after mandatory additions and deductions) for customs purposes. When a transfer price is set in accordance with the APA, that price should be accepted as a proper basis for the transaction value for customs purposes (Marsilla, 2008, p. 32). Beyond this consensus, involvement of customs authority to the APA negotiations process relieves all the stakeholders by reducing probable litigation expenses and risk of double taxation.

Application of joint APA brings up several administrative and procedural issues. For instance, establishment of a negotiation committee, assignment of applicable methods, evaluation and monitoring process, etc. Those issues require a policy mix approach to handle the conflict especially a joint commission can undertake responsibility to reconcile conflicting interests. 
Consequences of joint APA: The customs and tax authorities may consult together for the elimination of double taxation. APA also provides a ground for more coordination between domestic administrations as it provides cooperation between competent authorities in the form of exchanges of information.

A joint APA could prevent wasting time and money due to audit and litigation of customs valuation and transfer pricing issues both for taxpayers and tax administrations. Gaining more experience in the APA procedures additionally give an advantage to the administrations to solve similar problems in the future. Through an APA program tax administrations have access to useful industry data and analysis of pricing methodologies in a cooperative environment. ( TP Guideline F13.)

\subsubsection{Application of transfer price adjustment by customs}

Transfer pricing adjustments often occur post importation situations in which a taxpayer applies a price not fit in the arm's length range for income tax purposes. The compensating adjustment, which could be applied upward or downward, is intended to reach the desired arm's length result from a tax perspective. Such a compensation necessarily influences customs and tax administrations revenue assumption. As such, retroactive adjustment is handled differently from the perspective of developing and developed countries. It appears that the key differentiator between developed and developing countries which is the presence of substantial dependency to the indirect taxes affects the government reaction to enforce customs authorities to apply post import compensative adjustment.

As mentioned before Turkish Customs Law allows tax refund in certain situations (4458 number Customs Law, Articles 210-217). In the application of the statute, tax refund is carried out where the tax return is canceled, or taxpayers reject the tax return for material mistakes or contrary to the agreements or in the cases that conditions determined by Council of Ministers by virtue of the international agreement that Turkey is the signatory county. As implemented by Australian Customs Authority, in addition to those conditions relevant part of the Customs Law should be amended as the customs refund if downward transfer pricing adjustments reduce customs duty retrospectively.

From this perspective share of customs duty in Turkey's tax revenue considerably small which is about less than $2 \%$ of the overall tax revenue. On the other hand, if the customs duty and corporate tax rates are compared since corporate tax rate is by far higher than that of customs duty overall effect of transfer pricing adjustment would be positive in the high profit sector. But note that if a company is run in a lower profit range, say less then $5 \%$, tax revenue loss will take place. In any case, possible revenue loss that might be appear after the customs admittance of the transfer pricing adjustment is negligible.

Furthermore, as Customs refer to transaction value method, "the price paid or payable" is taken as a basis. In this context, a compensative post import adjustment would be evaluated in the scope of "the price paid or payable." Because, transfer pricing adjustment is justified as adapting a transaction value to the arm's length price which would be eventually meets the expression of " the price paid or payable" (Renaud, 2010, p. 2).

\subsubsection{Establishing transfer pricing and customs valuation review committee}

Integration of two administrations under one roof might be seen reasonable to reduce administrative cost, however, it is not practical as those two administrations have separate interest field other than related company importations (Sandra, 2009, p. 306). The scope of customs valuation encompasses transactions with non-associated enterprises which are out of the scope of transfer pricing, while the scope of transfer pricing encompasses export as well as import transactions and transactions consisting in the provision of services or transfer of intangible property, which may not be of great interest to customs authorities.

For sure, under the consideration of the nature of these two systems, through functionality of an intermediary joint commission all parties would benefit from better cooperation between the customs and tax authorities. In addition, customs and transfer pricing conflict can only be eased by better 
coordination and communication. Thus, with a joint commission, coordination and communication opportunities would be enhanced.

\section{Conclusion}

Today, that more effort should be geared towards reaching a consensus between transfer pricing and customs valuation is a notion on which all stakeholders are agree. Undisputedly the ideal situation could be defined as "where a tax authority assesses the arm's length principle of a transaction price, it would be consistent to have the same price accepted for customs purposes and vice versa." Ongoing fundamental differences between customs and tax authority does not allow to reach such an ideal in the short run. "When the differences between those two values can be bridged with adjustments, consistency should be the guiding principle, both for the authorities and taxpayers" (Marsilla, 2008, p. 14). Accordingly any policy approach intended to ease the conflict should necessarily include an applicable coordination plan either some degree of integration in administrative base or an assigned joint commission.

Management of the customs and transfer pricing tension needs to be undertaken proactively, and where appropriate in collaboration with tax authorities, to ensure that overall cash tax is correct and to minimize exposure to penalties and interest (Hickman et al., 2010, p. 538). Enhancing interaction between administrations with join training and dispute resolution groups support stabilization in the economic environment for both taxpayers and executive bodies by reducing number of uncertainties. Turkey is in the early stage of the conflicts that MNEs induce. Peer based learning and best practices should be taken seriously as a useful tools.

As mentioned earlier, both sets of rules require that an "arm's length" or "fair" value be set for cross-border transactions between related parties and associated enterprises (Ping and Silberztein, 2007, p. 36). That is, the transfer price must not be influenced by the relationship between the parties or it must be set in the same way as if the parties were not related. From this perspective it is seen that both sets of rules intend to ensure same principle by applying their own way. Even, those ways are not considerably irrelevant. Thus, two sets of rules say same ideal by using different languages. Those hurdles could be defeated by increasing communication opportunities among stakeholders.

\section{Bibliography}

Ainsworth, R. T. (2007). IT-APAs: Harmonizing Inconsistent Transfer Pricing Rules In Income Tax - Customs Vat. Boston: Boston University. Retrieved from:

http://www.bu.edu/law/faculty/scholarship/workingpapers/2007.html

An, H., Gambardella, D. \& Ritchie, Z. (2013). Transfer Pricing and Customs Nirvana: Is It Possible?. Bloomberg $B N A, 18(17)$.

Doernberg, R. L. (2004). International Taxation in a Nutshell. Thomson/West.

Duarte Nuno T. F.R. (2012). The tension between Transfer Pricing and Customs Valuation. Lisbon: ISEG.

Gustafson, C. H., Peroni , R. J. \& Pugh, R. C. (2006). Taxation of International Transactions; Materials, Text and Problems, 3th Edition. Thomson West.

Hickman, A. \& Bacon, M. (2009). "United Kingdom" in Transfer Pricing and Customs Valuation ed. Anuschka Bakker and Belema Obuoforibo. Amsterdam: IBFD, 530.

Jovanovich, M. J. (2017). Customs Valuation and Transfer Pricing, Is it Possible to Harmonize Customs and Tax Rules?. Kluwer Law, Montreal.

Kitaura, M. \& Cremer I. (2011). "Customs Value" in Transfer Pricing and Customs Valuation ed. Anuschka Bakker and Belema Obuoforibo, (Amsterdam: IBFD, 2009), 59-91.

Loknathan, V. (2018). History of economic thought, $10^{\text {th }}$ Edition. S Chand \& Co Ltd.

Malm, M. (2009). Customs Valuation and Transfer Pricing - Two sides of the Same Coin, Jonkopink University, Master Thesis. Retrieved from: http://hj.diva-portal.org/smash/record.jsf?pid=diva2:281537

Marsilla, S. I. (2008). Customs Valuation and Transfer Pricing. Berlin/Heidelberg: ERA Forum-Springer, 9/3. 
Methenitis, B. \& King, K. (2010). Supporting Transaction Value with Transfer Pricing Data: Lessons from Recent U.S. Customs and Border Protection Rulings. Bloomberg BNA, 19/3.

Ping, L. \& Silberztein, C. (2007). Transfer Pricing, Customs Duties and VAT Rules: Can We Bridge the Gap?. World Commerce Review. Retrieved from http://www.oecd.org/tax/transferpricing/transferpricingcustomsdutiesandvatrulescanwebridgethegap.htm

Renaud, P. (2010). Customs Valuation And Its Interaction With Transfer Pricing. Financier Worldwide. Retrieved from Http://Www.Financierworldwide.Com/Article.Php?Id=5670

Ritchie, Z. (2009). “Australia” in Transfer Pricing and Customs Valuation ed. Anuschka Bakker, and Belema Obuoforibo. Amsterdam: IBFD, 247-267.

Sandra G. (2009). "Canada” in Transfer Pricing and Customs Valuation ed. Anuschka Bakker and Belema Obuoforibo. Amsterdam: IBFD, 287-317

Silberzten, C. (2009). Transfer Pricing, OECD Policy Framework, in Transfer Pricing and Customs Valuation, ed. Anuschka Bakker and Belema Obuoforibo. Amsterdam: IBFD, 33-59.

Tropin, M. (2007). Australia, BNA, Transfer Pricing Report 88. Brussels.

Zinkin, R. \& Louis, J. (2019). Better Governance Across the Board. Creating Value Through Reputation, People, and Processes. Berlin. Boston: De Gruyter. Retrieved 21 Aug. 2019, from https://www.degruyter.com/view/product/508482

4458 no. Turkish Customs Act.

Australian Customs and Border Protection Service, Practice Statement No; PS 2009/01

Australian Customs and Border Protection Service, Practice Statement of Valuation Advice relating to Transfer Pricing.

Canada Customs Agency, (2006), Income Tax Transfer Pricing And Customs Valuation, Memorandum D-13-36.

HMRC. International Manual INTM 480000.

HMRC. Notice 252, July 2013.

OECD. Transfer Pricing Guidelines for Multinational Enterprises and Tax Administrations, 2010.

WCO. Agreement On Implementation Of Article Vii Of The General Agreement On Tariffs And Trade 1994. 